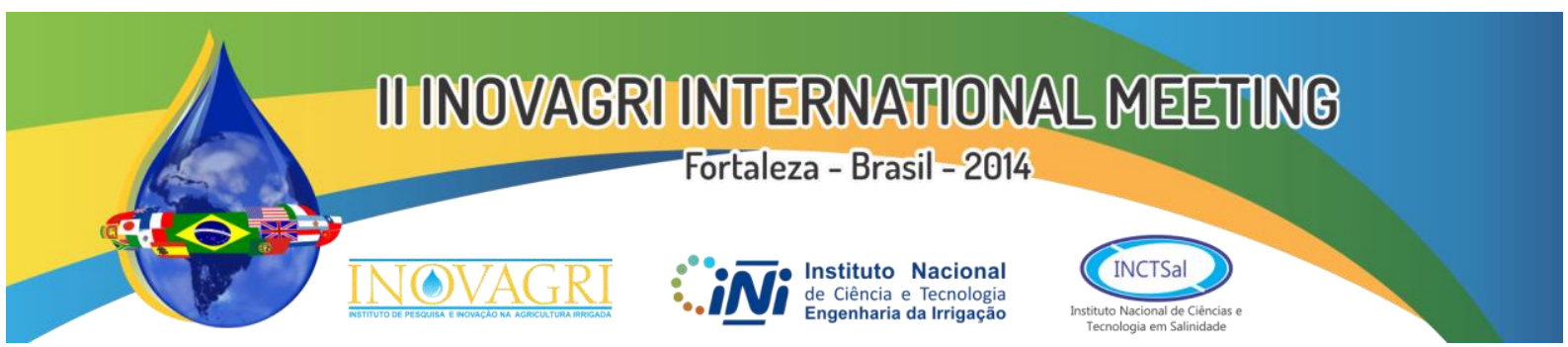

http://dx.doi.org/10.12702/ii.inovagri.2014-a043

\title{
IRRIGATION WATER STRATEGIES FOR THE BURITI VERMELHO WATERSHED: TOWARDS A HIGHER WATER PRODUCTIVITY
}

\author{
L.N. Rodrigues ${ }^{1}$, W.A.M. van Vliet $^{2}$
}

\begin{abstract}
As water is required to be used more efficiently, the crop water productivity should be improved. The main objective of this paper was to assess both the crop water productivity and the possibility to expand irrigated land in the Buriti Vermelho experimental watershed, Brazil. Soil-WaterAtmosphere-Plant (SWAP) model was used to perform the analysis. Buriti Vermelho contains both rain fed (soybean and corn) and irrigated (corn, common beans and wheat) crops. The crop water productivity was calculated as a function of total applied water, which includes the sum of irrigation and precipitation. An additional study was performed to verify the most ideal rainfed soybean growth period. The crop water productivity varied from $0.32 \mathrm{~kg} \mathrm{~m}^{-3}$ for soybeans to $1.90 \mathrm{~kg} \mathrm{~m}^{-3}$ for wheat. The crop water productivity decreased when the irrigation amount increased. Irrigation showed to have a big influence on the crop yield of common beans, wheat and rainfed corn, caused by a combination of low rainfall and low actual evapotranspiration values with higher irrigation requirements. The results showed November as being the most optimal growth period for soybeans. This month showed both the optimal yield as maximum crop water productivity. The future forecasts a decrease in crop water productivity, what means more water will be needed to reach the same amount of crop yield.
\end{abstract}

KEYWORDS: Water resources, water productivity, SWAP.

\section{ESTRATÉGIAS DE IRRIGAÇÃO PARA A BACIA HIDROGRÁFICA DO BURITI VERMELHO: ABORDAGEM COM VISTA AO AUMENTO DA PRODUTIVIDADE DE USO DA ÁGUA}

RESUMO: Com a necessidade de se utilizar a água de forma cada vez mais eficientemente, faz necessário melhorar a produtividade de uso da água em escala de bacia hidrográfica. Este estudo objetivou avaliar a produtividade de uso da água e a possibilidade de aumentar a área irrigada na bacia hidrográfica do Buriti Vermelho, Brasil. o modelo de Solo-Água-Atmosfera-Planta (SWAP) foi utilizado nas simulações. A bacia do Buriti Vermelho possui agricultura de sequeiro (soja e milho), e irrigada (milho, feijão e trigo). A produtividade de uso da água (CWP) foi calculada em função da lâmina total de água aplicada, que inclui a soma da irrigação e da precipitação. Avaliou-se também o período ideal para o plantio da soja, buscando-se o rendimento ótimo e a maior CWP. A CWP variou de $0,32 \mathrm{~kg} \mathrm{~m}^{-3}$, para a cultura da soja, a $1,90 \mathrm{~kg} \mathrm{~m}^{-3}$ para o trigo. Para o período estudado houve uma redução da CWP com o aumento da lâmina de irrigação. A irrigação mostrou ter grande influência no rendimento das culturas do feijão, do trigo e do milho. $\mathrm{O}$ rendimento ótimo e a máxima produtividade de uso da água para a soja foram observados no mês de novembro. O cenário futuro mostrou que haverá decréscimo na CWP e que será necessário aplicar mais água para se conseguir as mesmas produtividades.

PALAVRAS-CHAVE: Recursos hídricos, produtividade da água, SWAP.

\footnotetext{
1 Researcher, Embrapa Cerrados, BR020, km18, CEP 73310970, Planaltina, DF. Phone (61) 33889959. e-mail: lineu.rodrigues@embrapa.br

${ }^{2}$ Master student, Wageningen University, The Netherland, e-mail: wilbert_van_vliet@hotmail.com
}

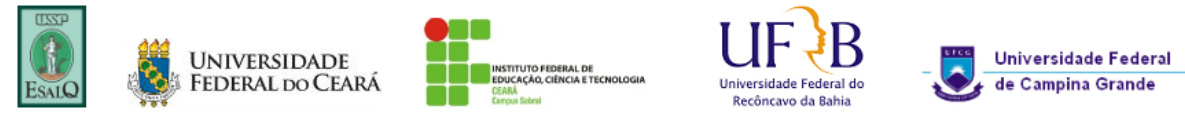




\section{INTRODUCTION}

The Buriti Vermelho experimental watershed is located in the central part of the Cerrado, the Brazilian Savannah. With an area of approximately 207 million hectares, the Cerrado is the last agricultural frontier in Brazil. Environmental conditions are characterized by adequate amounts of rainfall from October to April while few precipitation events are registered from May to September. In this region irrigated agriculture is expanding rapidly, but in a disorganized way and water conflicts among sectors can be identified. Water availability is the main constraint for crop production in the basin. Expanding irrigated land will demand more water, and this must be done within the context of an integrated management plan to prevent conflicts with other water uses. There is a pressing need to achieve a substantially more efficient and productive use of water in irrigation in the Buriti basin. Improvements in crop water productivity have the potential to improve both food security and water sustainability. Increasing the productivity of water means, in its broadest sense, getting more value or benefit from each drop of water used for crops. It provides a means both to ease water scarcity and to leave more water for other human and ecosystem uses (Kijne et al., 2003). Assessment of multiple irrigation management options can help to identify the irrigation strategy to increase water productivity. Field studies are helpful in determining and analyzing different irrigation management alternatives, but they are expensive and time-consuming. On the contrary, simulation models can be used with much lower expense and in shorter time after being calibrated for different irrigation options (Damaneh et al., 2013). Several simulation models have been developed in the last decade. Among those, the agro-hydrological SWAP (Soil, Water, Atmosphere and Plant) model based on the Richards equation focuses particularly on irrigation and drainage assessments (Kroes and van Dam, 2003). One advantage of the SWAP model is that it has been applied and tested under many different conditions and locations (Ma et al., 2013; Dung, 2001). Kiani \& Homayi (2007) evaluated SWAP model in wheat fields of Northern Gorgan, Iran for two growing seasons. Their statistical analyses showed that SWAP simulated quite well soil moisture and salinity and the relative yield of wheat. An increased water demand and increased emphasis on environmental issues has already motivated regulatory authorities to reconsider water allocation processes in several watersheds in the Cerrado region. It is important then to evaluate irrigation strategies, looking ways to increase water productivity and possibility to expand irrigated agriculture in the Cerrados. The assessment should be done taking into account rainfed and irrigated crops and the current and future scenarios. The objective of this paper was, therefore, was to assess both the crop water productivity and the possibility to expand irrigated land in the Buriti Vermelho experimental watershed, Brazil, taking into account rainfed and irrigated crops and the current and future scenarios.

\section{MATERIAL AND METHODS}

Study Area: Buriti Vermelho (BV) watershed is located in the central part of the Cerrado and also is part of the Sâo Francisco basin, which is located in the northeast part of the country covering about $630,000 \mathrm{~km}^{2}$. The BV basin has a tropical wet and dry climate, with a long dry season lasting from May to September, and rainy season that usually starts around October and ends in April. The average annual rainfall is around $1,200 \mathrm{~mm}$, of which $85 \%$ occurs during the rainy season. The length of the dry season contributes to various problems with water shortages and conflicts, and insecure food production. The geological environment of the Basin consists basically of low-grade metamorphic rocks (Rodrigues, 2012) and soil is composed of the following classes: Udic Oxisol (87.4\%), Ustic (3.5\%), Cambisol (5.4\%), Haplic Gleysoil (3.7\%). Center pivot is the main type of irrigation with corn, beans and wheat being the most common irrigated crops. Rainfed crops in the basin occupy an area of 1070 ha and soybeans and corn are the main crops planted. Water for irrigation is mainly extracted from the Buriti Vermelho River. Since the river is considered to be the main water source for irrigation, it plays a key role when determining the potential to expand irrigated land.

Simulation model: The Soil-Water-Atmosphere-Plant (SWAP) model (van Dam et al., 2008) was used in the simulations. The SWAP model is a physically based, detailed agro-hydrological model that simulates the relationships between soil, water, weather and plants. The core of the model is the Richards' equation where the transport of soil water is modeled by combining Darcy's law and the law 
of continuity (Ines et al., 2001). SWAP offers its users a whole range of new possibilities to address both research and practical applications in the field of agriculture, water management and environmental problems (Dung, 2001). Its new version is user-friendly and has the capability of simulating the movement of water, minerals and heat and planning the irrigation (Damaneh et al., 2013). Water movement, including root water uptake by a crop, is modeled using the Richards' equation (Noory et al., 2011). The water retention and hydraulic conductivity functions relate volumetric moisture content, with soil water pressure head and hydraulic conductivity according to van Genuchten (1980) and Mualem (1976). SWAP is a one dimensional model with only vertical flow. Once in the saturated soil, the flow pattern changes in a two dimensional pattern according to the soil water gradient. The lower boundary is therefore present in the unsaturated zone or the upper part of the saturated zone. SWAP gives the option between three types of boundary conditions consisting of the Dirichlet condition (prescribed groundwater level), Neumann condition (prescribed flux) and Cauchy condition (flux $=\mathrm{f}$ (pressure head)) (van Vliet, 2012). Potential crop evapotranspiration is estimated by the Penman-Monteith equation, using daily weather data and crop properties (Allen et al., 1998; Shuttleworth, 2006). Potential soil evaporation is calculated with the Penman-Monteith equation, using crop resistance $=0$, surface albedo $=0.15$, and crop height $=1 \mathrm{~mm}$ and is corrected for leaf area index according to Goudriaan (1977). SWAP gives three options to derive potential evapotranspiration rates for uniform surfaces; bare soil, dry canopy and wet canopy. It calculates these evapotranspiration rates by varying the crop resistance, crop height and reflection coefficient and includes both a simple and detailed crop growth module. SWAP offers three types of crop modules; a simple crop growth model, a detailed module for all kinds of crops (WOFOST) and a detailed module for grass growth. The simple crop model, used in this work, computes the crop development, independent of external stress factors. The detailed crop growth module is based on the World Food Studies (WOFOST) model which simulates crop growth and its production based on the incoming photosynthetically active radiation absorbed by crop canopy and photosynthetic characteristics of leaf (van Dam et al., 2008). SWAP gives two difference ways for the input of irrigation data; fixed or scheduled regime. In the fixed regime it is important to define the time and depth of irrigation application while the scheduled regime is defined by different times and depths. As a third option it is possible to define a combination of these two. Here, it is possible to calculate the water productivity in several different circumstances of water stress. In agriculture, this is called a crop coefficient (van Vliet, 2012).

\section{Data Collection and analysis}

Meteorological data: SWAP model requires data of weather, crop and soil. Meteorological data (minimum and maximum air temperature, relative humidity, solar radiation, wind speed and precipitation) were collected. Weather data from Embrapa Cerrados (CPACs) main station was used as reference in the simulations. This station is located about $50 \mathrm{~km}$ from the basin, but has the longest dataset, 30 years. Assessment of weather data integrity and quality need to be conducted before the data are utilized (Allen, 1996). To fill in the missing values and replace outliers, data from two other weather stations were used. One of them is located inside the basin (BVs) and has only five years of data recorded. The other is located $30 \mathrm{~km}$ apart (PADFs) of the basin and has recording period of 20 years. Statistical z-test was used to identify outliers, which were discarded from the sample. Regression equations among variables of the different stations were developed and used to fill up missing data or discarded outliers, where possible. Net solar radiation measurements were compared with the calculated extraterrestrial radiation, and when net solar was greater than extraterrestrial radiation, the net value was discarded. Furthermore, it was also tried to find correlations between weather variables of the same weather stations, like, for instance, maximum and minimum temperature, but the equations obtained in this analysis was not adequate to fill up the gaps. After all, the dataset used was from 1st of January 1999 to 2011. To finalize the data integrity analysis, a final check was performed, comparing different variables of our final dataset, used as input in SWAP, with a nearby FAO (Food and Agriculture Organization of the United Nations) weather station. The FAO weather station of Formosa was used. This weather station is located around 60 kilometers from CPACs. The mean values were calculated over a period of 15 years (1975 to 2000). To make a comparison with FAO data possible, CPACs monthly average was calculated. It was observed a good correlation, varying between 0.81 and 0.98 for almost all weather variables. 
Soil data: Soil was collected in the center pivot and rainfed areas. In each one of the areas, the soil profile was divided in three layers, being two layers in the topsoil $(0-5$ and $15-20 \mathrm{~cm})$ and the other in the subsoil horizon $(60-65 \mathrm{~cm})$. Three soil core samples were taken in each layer. At the end 27 soil samples were collected. Once was not observed much difference in the soil texture in the basin, an average of each layer was calculated and just two soil sample were used, one to represent the center pivots area and the other the rainfed. The soil water retention properties for core samples were determined by using the centrifugation method (Russel and Richards, 1938). The water retention properties were determined by using core soil samples (Silva et al., 2006). Gravimetric water contents $\left(\mathrm{kg} \mathrm{kg}^{-1}\right)$ at $-1,-3,-6,-10,-33,-80,-400,-1000$, and $-1500 \mathrm{kPa}$ water potential were determined. For every soil, samples were first saturated for $24 \mathrm{~h}$ and then weighed to determine the soil water content at saturation.

Crop data: SWAP gives the option to define whether the growth period is variable or fixed. Here the fixed case was used. The Leaf area index (LAI) and maximum root depth values for each crop were obtained from Rodrigues et al., 2011. The water stress coefficients are crop dependent and determine the root water extraction and thereby the actual transpiration. They were estimated for each crop. The crop rotation current dates implemented into the SWAP model are presented in Table 1 and Table 2 and were kept equal every year, to make a comparison easier; the simulation started for both crop rotations at first of November. Corn, common beans and wheat were irrigated and soybean and corn fedcrop. Corn is always planted after soybeans. A special focus was given to corn which was simulated as both irrigated and as rainfed. To find the most optimal planting date for Soybeans it was simulated with different planting dates and chosen goal (maximize crop water productivity or to optimize the crop yield).

Table 1 - Irrigated crop rotation dates

\begin{tabular}{|c|c|c|c|c|c|c|c|}
\hline Crop type & $\begin{array}{l}\text { Plant } \\
\text { date }\end{array}$ & $\begin{array}{l}\text { Harvest } \\
\text { date }\end{array}$ & $\begin{array}{l}\text { Growth } \\
\text { period } \\
\text { duration } \\
\text { (days) }\end{array}$ & Crop type & Plant date & $\begin{array}{l}\text { Harvest } \\
\text { date }\end{array}$ & $\begin{array}{l}\text { Growth } \\
\text { period } \\
\text { duration } \\
\text { (days) }\end{array}$ \\
\hline $\begin{array}{l}\text { Irrigated } \\
\text { corn }\end{array}$ & 1-nov & $27-f e b$ & 118 & Soybeans & 1-nov & $2-m r t$ & 121 \\
\hline Rest & 27-febr & 8-mar & 10 & Rest & 2-mrt & 12-mrt & 10 \\
\hline $\begin{array}{l}\text { Common } \\
\text { bean }\end{array}$ & 8-mar & 22-jun & 106 & Corn & 12-mrt & 8-jul & 118 \\
\hline Rest & 22-jun & 2-jul & 10 & & & & \\
\hline $\begin{array}{l}\text { Irrigated } \\
\text { wheat }\end{array}$ & 2-jul & 22 -oct & 112 & & & & \\
\hline Rest & 22-oct & 1-nov & 10 & & & & \\
\hline
\end{tabular}

Simulations: Simulations were performed to maximize crop water productivity, optimize crop yield and optimize irrigation management. It was evaluated irrigated and rainfed crops and current and future scenarios.

(i) Optimal irrigation: The threshold for irrigation is given in SWAP as a ratio of actual with potential transpiration. When the actual transpiration, and so the ratio, becomes too low, irrigation was applied to reach the threshold. For optimal irrigation, the ratio was defined as 0.9. This means that the actual transpiration has to be $90 \%$ of the potential transpiration. The potential crop yield can only be reached when the water supply was not limiting for crop growth.

(ii) Maximize crop water productivity: Instead of obtained the maximum crop yield, crop water productivity was maximized. This can be especially important in areas such as Buriti Vermelho, where water is scarce. Several definitions to calculate crop water productivity (CWP) are available. One of them is to calculate the CWP as a function of water input. This can give insight in the input needed to achieve a maximum yield or to use irrigation water more efficient according the aim (maximize crop water productivity or optimize crop yield). Only the CWP as a function of total applied water was used (Equation 1) and the deficit irrigation strategy was applied for the calculation of the maximum value. In this case less water is used than the plant actually requires in the most optimum case. When the maximum CWP was known, the belonging value for water stress was determined and used in the calculation for total profit and output yield in comparison with the current situation. 
$\operatorname{CWP}(\mathrm{I}+\mathrm{P})=\frac{\frac{E T a}{E T p}+Y m}{(I+P) * 100}$

Where: $\mathrm{ETa}=$ actual evapotranspiration, $\mathrm{cm} \mathrm{day}^{-1} ; \mathrm{ETp}=$ potential evapotranspiration, $\mathrm{cm} \mathrm{day}^{-1} ; \mathrm{Ym}$ $=$ maximum crop yield, $\mathrm{kg} \mathrm{ha}^{-1} ; \mathrm{I}=$ irrigation, $\mathrm{cm} ; \mathrm{P}=$ precipitation, $\mathrm{cm}$.

(iii) Future scenarios: According to the IPCC report of 2007, an increase of 2 degrees is expected for South America from 2000 until 2050 (Christensen, et al., 2007). The output of the Global NEWS model (Seitzinger, et al., 2010) was used to analyze the difference in precipitation between 2000 and 2050. It showed an annual increase of $9.09 \%$. An expected increase in temperature will possibly lead to a higher evapotranspiration. These changes were applied to the current climate dataset and projected for the period 2040 to 2050 and simulation performed. In the simulations the current situation uses input weather data from 1st of November, 1999 until the 31st of October, 2011 and the future from the 1st of November, 2040 to the 31st October, 2049. The annual start is assumed to be the 1st of November while the end is the 31 st of October. These dates are chosen to make comparison between the two types of irrigation easier, since the rain fed crop rotation starts annually around the 1 st of November.

(iv) Possibility to expand irrigation land: The potential for expanding irrigated land in the Buriti Vermelho basin was evaluated, analyzing the main source of water supply for irrigation, potential irrigated land with optimum crop yield and potential irrigated land with maximum crop water productivity. It is assumed that the total size of the study area cannot expand more, so parts of the rainfed area will turn into irrigated land. To start the simulation, first the total water availability in a crop growth period was calculated. This was done by taking the sum of the daily differences between the threshold value and actual discharge. The ecological minimum flow, Q90, was used as threshold and for the Buriti Vermelho River was $6,677 \mathrm{~m}^{3} \mathrm{~d}^{-1}$. The threshold approach resulted in 15 drought periods with an average duration of 8 days and a drought deficit of $130 \mathrm{~m}^{3}$ for the available dataset from May 2007 to July 2010. The next step consisted in dividing the total sum by the water use of the crop per hectare. This value is crop specific. The irrigated land can expand until also the rainfed land potential is reached or until the minimum flow in the BV River is reached. The results of crop yield and income was compared to the current situation. It shows whether the increase in irrigated land will lead to more income or to a loss. With input of the crop yield per hectare, specific for Buriti Vermelho, the total yield output was calculated. Index Mundi was used as reference to the world food prices per ton crop yield (Index Mundi, 2012).

(v) Estimative of the best sowing date for soybean: In the BV basin soybeans is a rainfed crop, being highly dependent of rainfall. It is important then to verify the most ideal sowing date, depending on the goal of reaching an optimum yield or the maximum CWP. For the simulations soybean was simulated as planted in November first, as usually farmers do. The same analysis was performed for three other sowing dates; 1st of October, 15th of October and 15th of November.

\section{RESULTS AND DISCUSSION}

The results were analyzed taken into account the current and future situations in both irrigated and rainfed crop rotation with special attention to crop water productivity (CWP) and crop yield. The future situation describes the expected change in the current situation. The analyses were performed taken into account parameter values (of 12 growing seasons) of CWP, crop yield, irrigation amount and precipitation. This analysis is expected to have a good representation over an average growing season.

\section{- Irrigated crop}

In the simulation corn was planted in the rainy season, from November to March. Common beans are planted when the precipitation already starts to decrease, in March. March and April show a decreasing trend in precipitation with respectively $143 \mathrm{~mm}$ and $69 \mathrm{~mm}$ in comparison with February $(164 \mathrm{~mm})$. Beans are sowed in June. This can lead to higher irrigation requirements. The growth 
period of wheat runs from June to October and is characterized by low rainfall; June and July only show average values of 0 and $1 \mathrm{~cm}$ of rainfall. This is expected to lead to high irrigation requirements for wheat. Figure 1 shows crop yield in function of both total applied water and crop water productivity for current and future scenarios.

\section{Crop yield versus total applied water}

\section{(a) Current situation}

In the current situation higher irrigation application has a positive influence on crop yield of beans and wheat. Corn did not show any change in crop yield given the amount of total applied water, once water obtained from precipitation was enough for production and irrigation made little difference (Figure 1a), even to reach optimal crop yield. Common beans was grown in a dryer period with total precipitation significantly lower. Applying an irrigation depth of $10 \mathrm{~cm}$, optimal crop yield increased in $110 \mathrm{~kg} \mathrm{ha}^{-1}$ and the total irrigation water in $40 \%$. The low precipitation observed during wheat season leads to a more prominent role of irrigation on crop yield. Applying $34 \mathrm{~cm}$ of irrigation depth observed and increase in yield to $3,600 \mathrm{~kg} \mathrm{ha}^{-1}$. Optimal crop yield $\left(4,100 \mathrm{~kg} \mathrm{ha}^{-1}\right)$ required $43 \mathrm{~cm}$. Optimal irrigation is preferred, once yield in rainfed decreased $67 \%$ when compared with maximum crop yield. FAO set up global minimum and maximum water use values to reach an optimal crop yield. The water demand value $\left(2,700 \mathrm{~m}^{3} \mathrm{ha}^{-1}\right)$ obtained for common beans falls in the range of global average proposed by FAO $\left(2,500\right.$ to $\left.5,000 \mathrm{~m}^{3} \mathrm{ha}^{-1}\right)$. Wheat used $5,100 \mathrm{~m}^{3} \mathrm{ha}^{-1}$ and FAO proposed a range varying from 4,500 to $6,500 \mathrm{~m}^{3} \mathrm{ha}^{-1}$. Corn was not analyzed because it used only rainfall.

\section{(b) Future situation}

An increase in temperature and precipitation in expected. This causes lower crop yields during rainfed and higher crop yields during optimal irrigation. Furthermore, both actual and potential evapotranspiration increased and so the water loss requirements for irrigation. Corn showed again a similar actual crop yield, with a small yield reduction in the future (Figure 1a), mainly caused by an increase in potential evapotranspiration from 38 to $50 \mathrm{~cm}$. The growth period of common beans showed a similar trend with an increasing precipitation amount, increasing crop yield during optimal irrigation, but also increasing irrigation requirements. Optimal crop yield increased from 1,670 to $1,740 \mathrm{~kg} \mathrm{ha}^{-1}$. However, when compared with current situation, more irrigation was required to reach the optimal crop yield (from $8 \mathrm{~cm}$, current, to $12 \mathrm{~cm}$, in the future). The conclusion is that the future forecasts an increase in both irrigation requirements and optimal crop yield, but a yield decrease for rainfed crop. Similar to the trends of corn and common beans, the water loss increased, demanding more irrigation water for wheat. Actual crop yield increased for optimal irrigation and also crop yield, from 4,170 to $4,240 \mathrm{~kg} \mathrm{ha}^{-1}$. Where the optimal crop yield in the current situation still required a total of $38 \mathrm{~cm}$ of irrigation water, the irrigation amount showed an increase to $47 \mathrm{~cm}$ for the future simulation. The increase in irrigation is caused by a higher water loss; the average actual evapotranspiration increase from 40 to $48 \mathrm{~cm}$ during the growth period.
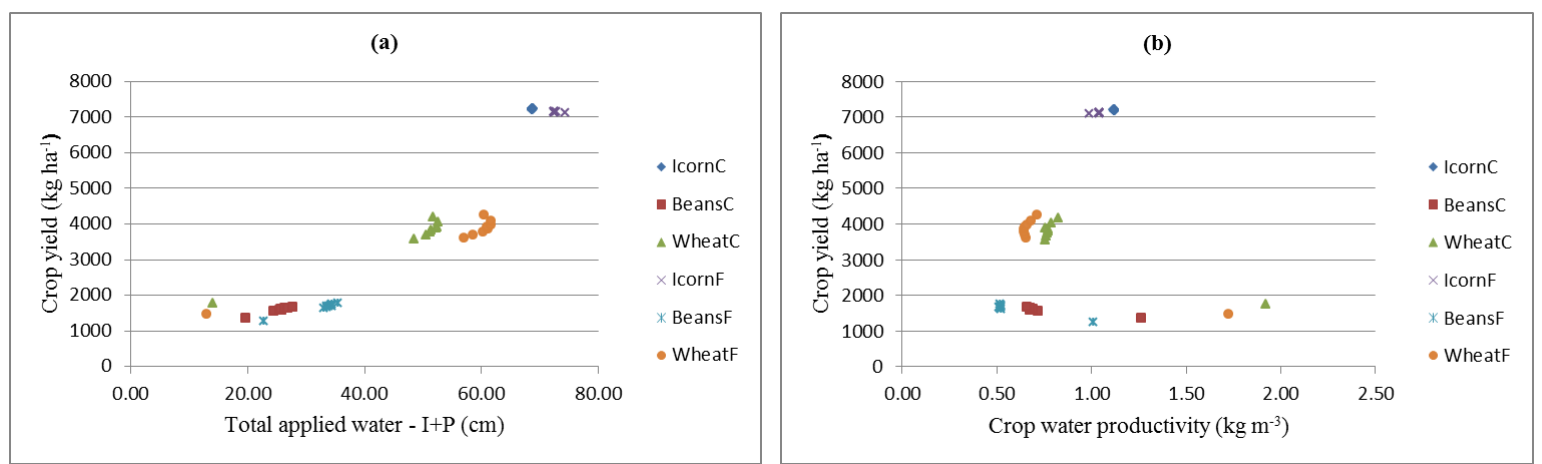

Figure 1 - Crop yield in function of both total applied water (a) and crop water productivity (b) for current and future. The letters $\mathrm{C}$ and $\mathrm{F}$ after the crop names stand for current and future, respectively. 


\section{Crop yield versus crop water productivity}

\section{(a) Current situation}

Corn showed an average CWP of $1.12 \mathrm{~kg} \mathrm{~m}^{-3}$ to a crop yield of 7,200 kg ha' (Figure 1b). Through the years it varied from $0.65 \mathrm{~kg} \mathrm{~m}^{-3}$ (2003) to $1.46 \mathrm{~kg} \mathrm{~m}^{-3}$ (2009). Zwart \& Bastiaanssen (2004) obtained CWP values varying from 1.10 to $2.70 \mathrm{~kg} \mathrm{~m}^{-3}$ and FAO (2012) suggested 0.8 to $1.6 \mathrm{~kg} \mathrm{~m}^{-3}$. A decrease in CWP to $0.75 \mathrm{~kg} \mathrm{~m}^{-3}$ implies in a slightly increase in crop yield of $250 \mathrm{~kg} \mathrm{ha}^{-1}$. This shows a little crop yield increase on a relative big change in crop water productivity. When decreasing the CWP to $0.66 \mathrm{~kg} \mathrm{~m}^{-3}$, the crop yield increases to an optimum average actual crop yield of $1,670 \mathrm{~kg} \mathrm{ha}^{-1}$. The average CWP value is slightly below the proposed range given by FAO (1.5 to $\left.2.0 \mathrm{~kg} \mathrm{~m}^{-3}\right)$ (FAO, 2012). When decreasing the CWP to $0.76 \mathrm{~kg} \mathrm{~m}^{-3}$, the increasing observed in crop yield more than double $\left(3,540 \mathrm{~kg} \mathrm{ha}^{-1}\right)$. This means a significant influence of CWP on crop yield, mainly caused by the low water availability during the growth period (precipitation) and thereby greater influence of irrigation on crop yield. The average global CWP for wheat varies from 0.6 to $1.8 \mathrm{~kg} \mathrm{~m}^{-3}$ (Zwart \& Bastiaanssen, 2004), thus the maximum CWP falls just above this range. FAO proposes 0.8 to $1.6 \mathrm{~kg}$ $\mathrm{m}^{-3}$ as world average CWP for wheat (FAO, 2012). This range is slightly exceeded. The rainfed situation causes a decrease of almost $70 \%$, where the maximum crop yield is considered to be 5,242 $\mathrm{kg} \mathrm{ha}^{-1}$. This is not economically feasible and thus optimal irrigation is preferred for wheat.

(b) Future situation

A small decrease in CWP was observed in corn with value of $1.00 \mathrm{~kg} \mathrm{~m}^{-3}$ (Figure 1b). During optimal irrigation CWP $\left(0.52 \mathrm{~kg} \mathrm{~m}^{-3}\right)$ was lower than in the current situation. This was caused by an increase in irrigation demand. Similar to common beans and corn, it was observed a decrease of maximum CPWP in wheat, from $1.90 \mathrm{~kg} \mathrm{~m}^{-3}$ to $1.72 \mathrm{~kg} \mathrm{~m}^{-3}$, showing that irrigation will even be more important in the future, and eventually this can lead to a CWP decrease when the target is optimal irrigation, where the current situation showed $0.82 \mathrm{~kg} \mathrm{~m}^{-3}$, the future shows $0.71 \mathrm{~kg} \mathrm{~m}^{-3}$.

\section{- Rainfed crop}

The rainfed crop rotation consists of soybeans and corn with a combined planted area of 968 ha. Soybeans are planted in November, during the start of the rainy season. Therefore little additional water was required. Soybeans were replaced by corn in March.

\section{Crop yield versus total applied water}

\section{(a) Current situation}

Soybeans were sowed and harvested during the rainy season. During this period the average precipitation was $69 \mathrm{~cm}$ and enough to attend corn water demand, so there is no need of additional irrigation. The average actual crop yield was $2,100 \mathrm{~kg} \mathrm{ha}^{-1}$, varying from 1,900 (2003/2004) to 2,300 $\mathrm{kg} \mathrm{ha}^{-1}(2000 / 2001)$. When corn was planted lower average precipitation was verified, $18 \mathrm{~cm}$. Rainfed crop showed an average actual crop yield of $2,970 \mathrm{~kg} \mathrm{ha}^{-1}$. With an average irrigation amount of $32 \mathrm{~cm}$ an optimal average crop yield of $3,230 \mathrm{~kg} \mathrm{ha}^{-1}$ can be obtained.

(b) Future situation

Precipitation increased for both soybeans and corn. In the future soybean yield will decrease to 2,070 $\mathrm{kg} \mathrm{ha}^{-1}$. The decrease in crop yield was caused by an increase in evapotranspiration values; the potential increased from 40 to $48 \mathrm{~cm}$ while the actual value increased from 31 to $37 \mathrm{~cm}$. Corn shows similar changes during its growth period. Where the crop yield of soybeans only decreases around 50 $\mathrm{kg} \mathrm{ha}^{-1}$, corn will decrease about $240 \mathrm{~kg} \mathrm{ha}^{-1}$ (from 2,970 to $2730 \mathrm{~kg} \mathrm{ha}^{-1}$ ). The precipitation amount within the growth period increased from 18 to $21 \mathrm{~cm}$.

\section{Crop water productivity versus crop yield}

(a) Current situation

As mentioned in the previous analysis, soybeans do not required irrigation. Not even during the optimal irrigation situation. This causes a constant CWP of $0.32 \mathrm{~kg} \mathrm{~m}^{-3}$, independently of rainfed or irrigation. CWP was found in FAO varying from 0.4 to $0.8 \mathrm{~kg} \mathrm{~m}^{-3}(\mathrm{FAO}, 2012)$. In some years was observed values of CPW as low as $0,19 \mathrm{~kg} \mathrm{~m}^{-3}$ in 2004, while other years showed a significant higher 
CWP with a maximum value of $0.55 \mathrm{~kg} \mathrm{~m}^{-3}$. Corn showed a maximum CWP of $3.40 \mathrm{~kg} \mathrm{~m}^{-3}$ corresponding to an average actual crop yield of $2,970 \mathrm{~kg} \mathrm{ha}^{-1}$.

(b) Future situation

The soybeans maximum CWP was $0.27 \mathrm{~kg} \mathrm{~m}^{-3}$ for a crop yield of about 2,000 kg ha-1, around $100 \mathrm{~kg}$ $\mathrm{ha}^{-1}$ lower than in the current situation. Corn has a maximum CWP of $2.70 \mathrm{~kg} \mathrm{ha}^{-1}$ corresponding to a crop yield of $2,730 \mathrm{~kg} \mathrm{ha}^{-1}$, similar to the current case. The maximum CWP decreases in the future from 3.30 to $2.70 \mathrm{~kg} \mathrm{ha}^{-1}$, what indicates a lower efficiency of water use. Furthermore a strong decrease in CWP (from 0.71 to $0.43 \mathrm{~kg} \mathrm{~m}^{-3}$ ) is noticeable during optimal irrigation, mainly caused by a much higher irrigation demands.

- Expand of irrigated land: The analysis of potential increase in the irrigated land included simulations with maximum crop yield and corresponding water use and adapted crop yield and water use. It also included input from the current prices per ton. When simulating annual three growth periods, irrigated corn gives the highest profit with more than 204,000.0 USD in comparison with the current situation. The simulation with the adapted crop yield and water use has input from the results of the simulations performed with every crop type. The values for water use and crop yield correspond here to the maximum crop water productivity. In case the crop yields which correspond to a maximum crop water productivity fall below the economically feasible threshold, the crop yields for optimum crop yield and water use are taken. When giving input with these values into developed model in Excel to calculate the increase of irrigated land, it showed only for rainfed corn and irrigated corn improvements in crop water productivity. In case of all other involved crop types, decreasing the water use proved not to be a good alternative.

\section{- Growth period of soybean}

Soybeans are known not to be irrigated and highly dependent of rainfall. This shows the importance of a separate analysis of the most ideal sowing date for soybeans, depending on the goal of reaching an optimum yield or the maximum CWP. The results show differences in rainfall amount, actual evapotranspiration and potential evapotranspiration. The highest average rainfall recorded when sowing soybean was 15 th of October $(79.88 \mathrm{~cm})$, while the lowest quantity was measured in 1st of October $(65.25 \mathrm{~cm})$. The actual and potential evapotranspiration show the highest average values at the 15th of October $(34,60 \mathrm{~cm}$ and $43,70 \mathrm{~cm})$ and the lowest values at respectively the 1st of October $(30,37 \mathrm{~cm})$ and the 1 st of November $(40,16 \mathrm{~cm})$. In order to analyze the optimal crop yield, a similar analysis was performed for the optimal irrigation case. Only when sowing soybean at the 15th of November, irrigation is required $(8 \mathrm{~cm})$. However, no significant increase in crop yield was observed (from 2,118 to $2,123 \mathrm{~kg} \mathrm{ha}^{-1}$ ). Crop water productivity for different sowing dates, showed minor differences ranging from $0.29 \mathrm{~kg} \mathrm{~m}^{-3}$, at the 15 th of October, to $0.33 \mathrm{~kg} \mathrm{~m}^{-3}$, at the 15 th of November. The corresponding crop yields were respectively 2,118 and $1,965 \mathrm{~kg} \mathrm{ha}^{-1}$, what means a decrease of $21.9 \%$ and $27.6 \%$ decrease of the maximum yield. All CWP values are hereby economically feasible ( $<40 \%$ decrease of the maximum yield). However, since the crop yields resulting from the sowing dates in November are approximately $8 \%$ higher than from the sowing dates in October, is advised to sow the crops in November. This gives the highest values for CWP and crop yield.

\section{CONCLUSIONS}

The ecological minimum flow for the Buriti Vermelho River was calculated as $6,677 \mathrm{~m}^{3} \mathrm{~d}^{-1}$. When combining the crop yield per hectare with water use and USD/ton, it was showed that corn brings the best opportunities to expand irrigation in the basin, while the least attractive was wheat. Three of the five simulated crops showed their maximum crop water productivity in case of rainfed. Common beans with $1.30 \mathrm{~kg} \mathrm{~m}^{-3}$, wheat with $1.90 \mathrm{~kg} \mathrm{~m}^{-3}$, and rainfed corn with $3.30 \mathrm{~kg} \mathrm{~m}^{-3}$. Simulations during the rainy season shoed that irrigated corn $\left(1.12 \mathrm{~kg} \mathrm{~m}^{-3}\right)$ and soybeans $\left(0.32 \mathrm{~kg} \mathrm{~m}^{-3}\right)$ needed little irrigation, this leads to equal CWP values for rainfed and irrigated. The maximum CWP are not all economically feasible. A combination with crop yield shoed a reduction of $67 \%$ for wheat and required a maximum water use to be profitable. An increase in irrigation application leads to decreasing CWP values. The highest decrease was seen for wheat, from 1.90 to $0.76 \mathrm{~kg} \mathrm{~m}^{-3}$, in case of optimal irrigation. The future trend of water availability foresaw an increase of the ratio of 
evapotranspiration (or crop growth), generally the potential value increases often more than the actual value. This leads to a reduction in crop growth during rainfed irrigation, but increase crop growth during optimal irrigation. The irrigation amounts during optimal irrigation show higher requirements in the future than in the current situation.

\section{ACKNOWLEDGMENTS}

The presented research was carried out as part of the project "Avaliação de estratégias de irrigação, de opções de alocação de recursos hídricos e de suas consequências econômicas para comunidades rurais: uma abordagem usando modelagem matemática". We gratefully acknowledge financial support of Conselho Nacional de Desenvolvimento Científico e Tecnológico (CNPq), Embrapa Cerrados and Wageningen University.

\section{REFERENCES}

ALLEN, R.G.; PEREIRA, L.S.; RAES, D.; SMITH, M. Crop evapotranspiration: guidelines for computing crop water requirements. Irrigation and Drainage, 1998, Paper 56, FAO, Rome, Italy.

ALLEN, R. Assessing Integrity of Weather Data for Reference Evapotranspiration Estimation. Journal of Irrigation and Drainage Engineering, V.122, n..2, p. 97-106, 1996. (doi: 10.1061/(ASCE)07339437(1996)122:2(97)). http://dx.doi.org/10.1061/(ASCE)0733-9437(1996)122:2(97)

CHRISTENSEN, J. et al., 2007. Regional Climate Projections in Climate Change 2007: The Physical Science Basis. Cambridge, United Kingdom and New York, NY, USA: Cambridge University Press.

DUNG, D. V. Evaluation of irrigation practice at farm level using GIS, RS Data and Swap Model: case study at Lake Naivasha Project, Kenya. 95f. 2001. Thesis (Master of Science in Water Resources and Environment Management) - International Institute for Aerospace Survey and Earth Sciences, Enschede, 2001.

FAO, 2012. FAO - Water Development and Management Unit - Information Resources - Databases. [Online] Available at: http://www.fao.org/nr/water/infores_databases_climwat.html [Accessed 232 2012].

Index Mundi, 2012. Agricultural Commodities - Production, Consumption, Exports, and Imports. [Online] Available at: http://www.indexmundi.com/ [Accessed 123 2012].

INES, A. V. M.; DROOGERS, P.; MAKIN, I. W.; DAS GUPTA, A. Crop growth and soil water balance modeling to explore water management options. Colombo, Sri Lanka: International Water Management Institute, 2001. (Working Paper, 22).

KIANI, A.R; HOMAYI, M. Evaluation of SWAP model in simulating the transport of water and minerals in soil profile. Journal of Agricultural Engineering Research, V.8, n.1, p. 13-30, 2007.

KROES, J.G.; van Dam, J.C. Reference manual SWAP version 3.03, Alterra Green World Research, Alterra Report 773, Wageningen University and Research Centre, Wageningen, The Netherlands, 2003. ISSN: 1566-7197.

MA, Y.; FENG, S.; HUO, Z.; Song, X. Application of the SWAP model to simulate the field water cycle under deficit irrigation in Beijing, China. Mathematical and Computer Modelling, V.54, n.34, p. 1044-1052, $2011 \quad$ http://dx.doi.org/10.1016/j.mcm.2010.11.034. http://dx.doi.org/10.1016/j.mcm.2010.11.034

MOGHABELIDAMANEH, I.; FARZADHASANPOUR, I.; BEHROUJ, M. Evaluation of HYDRUS1D and SWAP Models in Simulating Water and Minerals Movement in Soil. Switzerland Research Park Journal, V.102, n.5, 2013.

MOLDEN, D.; MURRAY-RUST, H.; SAKTHIVADIVEL, R.; MAKIN, I. A water-productivity framework for understanding and action. In: KIJNE, J. W.; BARKER, R.; MOLDEN, D. (Ed.). Water productivity in agriculture: limits and opportunities for improvement. London: $\mathrm{CAB}$ International: International Water Management Institute, $2003 . \quad$ p. 17. http://dx.doi.org/10.1079/9780851996691.0001

MUALEM, Y. A new model for predicting the hydraulic conductivity of unsaturated porous media. Water Resour. Res, V.12, p. 513-522, 1976. http://dx.doi.org/10.1029/WR012i003p00513 
GOUDRIAAN, J. Crop Meteorology: A Simulation Study. Simulation Monographs Pudoc, Wageningen, The Netherlands, 1977.

NOORY, H.; van der ZEE, S.E.A.T.M.; LIAGHAT, A.M.; PARSINEJAD, M.; van DAM, J.C. Distributed agro-hydrological modeling with SWAP to improve water and salt management of the Voshmgir Irrigation and Drainage Network in Northern Iran. Agricultural Water Management, V.98, n.6, p. 1062-1070, 2011. http://dx.doi.org/10.1016/j.agwat.2011.01.013. http://dx.doi.org/10.1016/j.agwat.2011.01.013

RODRIGUES, L.N.; SANO, E.E.; STEENHUIS, T.S.; PASSO, D.P. Estimation of Small Reservoir Storage Capacities with Remote Sensing in the Brazilian Savannah Region. Water Resources Management, V. 26, p. 873-882, 2012. http://dx.doi.org/10.1007/s11269-011-9941-8

RODRIGUES, L.N.; MARIOTI, J.; MORAES JUNIOR, A.R. Índice de área foliar e profundidade radicular máxima das principais coberturas vegetais de uma bacia hidrográfica do bioma Cerrado. In: XL Congresso Brasileiro de Engenharia Agrícola, 2011, Cuiabá. Geração de tecnologias inovadoras e o desenvolvimento do Cerrado brasileiro, 2011.

RUSSEL, M.B.; RICHARDS, L.A. The determination of soil moisture energy relations by centrifugation. Soil Sci. Soc. Am. Proc., V.3, p. 65-69, 1938.

SEITZINGER, S. P., MAYORGA, E., BOUWMAN, A. F., KROEZE, C., BEUSEN, A. H. W., BILLEN, G., VAN DRECHT, G., DUMONT, E., FEKETE, B. M., GARNIER, J. \& HARRISON, J. A. 2010. Global river nutrient export: A scenario analysis of past and future trends. Global Biogeochem. Cycles, 24, GB0A08. http://dx.doi.org/10.1029/2009GB003587

SILVA, E.M.; LIMA, J.E.F.W.; Azevedo, J.A.; RODRIGUES , L.N. Valores de tensao na determinacao da curva de retencao de agua de solos do Cerrado. Pesqui. Agropecu. Bras., V. 41, p. 323-330, 2006. http://dx.doi.org/10.1590/S0100-204X2006000200018

SHUTTLEWORTH, W.J. Towards one-step estimation of crop water requirements. Trans. ASABE, V.49, p. 925-935, 2006. http://dx.doi.org/10.13031/2013.21738

van GENUCHTEN, M.Th. A closed form equation for predicting the hydraulic conductivity of unsaturated soils. Soil Sci. Soc. Am. J, V.44, p. 892-898, 1980. http://dx.doi.org/10.2136/sssaj1980.03615995004400050002x

van VLIET, W. Irrigation water strategies for catchment Buriti Vermelho: towards a higher water productivity. 82f. 2002. Thesis (Master) - Wageningen University, Wageningen, 2012.

ZWART, S. J.; BASTIAANSSEN, W. G., 2004. Review of measured cropwaterproductivity values for irrigated wheat, rice, cotton and maize. Agricultural Water Management, 2(69), pp. 115-133. http://dx.doi.org/10.1016/j.agwat.2004.04.007 